\title{
Antibiofilm Competency of Portunus pelagicus Haemolymph and Identification of its Bioactive Compounds
} Mahalingam Anjugam ${ }^{1}$, Arokiadhas Iswarya $^{1}$, Thiruselvam Indumathi', Baskaralingam Vaseeharan ${ }^{1 *}$, Raman Pachaiappan $^{2}$, Narayanan Gopi ${ }^{1}$
and Palaniyandi Velusamy

${ }^{1}$ Crustacean Molecular Biology and Genomics Division, Biomaterials and Biotechnology in Animal Health Lab, Department of Animal Health and Management, Alagappa University, Science Block 4th floor, Burma colony, Karaikudi-630004, Tamil Nadu, India

${ }^{2}$ Department of Biotechnology, School of Bioengineering, SRM University, Kattankulathur 603 203, Tamil Nadu, India

\begin{abstract}
The marine atmosphere may be investigated as a rich source for novel drugs. In past decades, a number of marine-derived compounds have been isolated and identified. The current effort was made on haemolymph of blue swimmer crab Portunus pelagicus to mark its antimicrobial activity against eight pathogenic bacteria of Gram positive, Gram negative and fungus Candida albicans. Agar well diffusion method was put into practice in deliverance of antibacterial and antifungal activity by measuring zone of inhibition. The findings displays, $P$. pelagicus haemolymph at the concentration of $150 \mu \mathrm{l}$ can effectively act against all of challenged bacteria and fungus. Besides, the antibiofilm property of haemolymph against selected bacteria and fungus $C$. albicans which revealed the potential bactericidal and fungicidal effect at $150 \mu \mathrm{l}$ concentration of haemolymph. Moreover, the antimicrobial and antibiofilm potent of crab haemolymph was confirmed by growth curve analysis, biofilm growth inhibition and protein leakage assay which collectively conclude the ability of haemolymph in microbial growth inhibition. For the first time, the bioactive compounds were screened from the haemolymph of $P$. pelagicus through Gas chromatography- Mass spectrometry analysis discloses the existence of 15 types of compounds in haemolymph being in charge for antimicrobial activity.
\end{abstract}

Keywords: Portunus pelagicus; Haemolymph; Antimicrobial activity; Bioactive compounds

\section{Introduction}

The ocean engages with almost three quarters of the earth's surface and contains an unexpected assortment of life [1]. A diverse array of natural products are seems to be presents in marine ecosystem with abundant of bioactive compounds and have the great potential for the production of pharmacological substances [2]. Part of the biodiversity was inhabited by marine organisms and the marine ecosystem is the greatest source to discover useful therapeutics [3]. Since the numbers of microorganisms which are mastery in quickly changing pattern of resistance to antibiotics have been increased steadfast, the necessities for treating these pathogens demand novel and successful antimicrobial agents. This makes researcher's move forward to the marine wealth due to the exploitation of the terrestrial resources. Bioactive compounds of marine source known to have clinical properties includes antitumor, antiproliferative, anticancer [4,5] antihypersensitive, antimicrotubule, antifouling [6] and antibiotic properties [7-9] and also have cosmeceutical applications [10] At present, only some marine-derived products are currently in the market, quite a few marine natural products are presently in the medical channel, with more undergoing enlargement $[11,12]$. So far, bioactive compounds for medical utilization were isolated from sponges (37\%), coelenterates $(21 \%)$ and microorganisms (18\%), are major sources of biomedical compounds, followed by algae (9\%), echinoderms (6\%), tunicates (6\%), molluscs (2\%) bryozoans (1\%), etc [13]. However, knowledge about bioactive compounds from arthropods is still insufficient. Being a member of arthropods, crustaceans formed various bioactive substances which posses the antimicrobial activity against pathogenic microbes [14]. In recent decades, the growing number of bacterial strains resistant to conservative antibiotics has evolved as a serious medical problem [15]. Marine pharmacology has been reviewed extensively in the past all over the world as well as in India, but as far as there is an inevitability to review the potential of the marine as foundation for the development of new drugs, considering the advantage of their wealth in nature and bulky invention [16]. Further, chemical compounds secluded from marine organisms have huge potential as antimicrobials or cytotoxic compounds due to the confidence of marine organisms on antimicrobial composites or cytotoxic molecules as their innate defense devices. Some crustaceans have shown pronounced activities, useful in biomedical area by the action of circulating haemolymph which contains biologically active substances such as complement, lectin [17], clotting factors [18] and antimicrobial peptides $[19,20]$, pattern recognition proteins [21]. Though marine crabs are a source of biologically active products, their importance in biomedical area is largely unexplored. The widespread knowledge in the chemical structure and physiological character of the bioactive substance in the crabs leads to the production of novel drugs with unique action. The crabs are to be prolific source of bioactive compounds but the researchers carried out so far regarding the pharmacological properties are scanty. Hence, an expansive viewing of marine crabs for bioactive compounds is compulsory. In this regard, an endeavour has been made to learn the antibacterial and antifungal activity of the blue swimmer crab Portunus pelagicus haemolymph against some selected clinical related pathogens such as Gram positive Bacillus pumulis, Staphylococcus aureus, Enterococcus faecalis; Gram negative Morganalla morganii, Proteus vulgaris, Pseudomonas aeruginosa, Vibrio parahaemolyticus, Citrobacter freundii and fungal pathogen Candida albicans. Nevertheless many findings report the

${ }^{*}$ Corresponding author: Dr. B. Vaseeharan, Crustacean Molecular Biology and Genomics Division Biomaterials and Biotechnology in Animal Health Lab, Department of Animal Health and Management, Alagappa University, Science Block 4th Floor, Burma Colony, Karaikudi- 630 004, Tamil Nadu, India, Tel: + 91 4565 225682; Fax: + 914565 225202; E-mail: vaseeharanb@gmail.com

Received July 20, 2016; Accepted August 29, 2016; Published August 31, 2016

Citation: Anjugam M, Iswarya A, Indumathi T, Vaseeharan B, Pachaiappan R et al. (2016) Antibiofilm Competency of Portunus pelagicus Haemolymph and Identification of its Bioactive Compounds. J Aquac Res Development 7: 444. doi: 10.4172/2155-9546.1000444

Copyright: (c 2016 Anjugam M, et al. This is an open-access article distributed under the terms of the Creative Commons Attribution License, which permits unrestricted use, distribution, and reproduction in any medium, provided the original author and source are credited. 
antibacterial and antifungal activity of crustacean's haemolymph, to the best of the author's knowledge this is the first attempt to discover the antibiofilm property of crab haemolymph. Formerly, antimicrobial activity of crustacean's haemolymph was reported in Charybdis lucifera [22], Paratelphusa hydrodromous [23] and Portunus segnis [24]. However, there was a lacking to summarize the compounds which are answerable for inhibiting the bacterial growth. In this regard, through GC-MS analysis, bioactive compounds were known from $P$. pelagicus haemolymph

\section{Materials and Methods \\ Collection of crabs and haemolymph}

The healthy crab $P$. pelagicus were collected from the coastal area of Thondi, Ramanathapuram District, Tamil Nadu, India and brought to the laboratory for the collection of haemolymph. Healthy intermoult animals with $7 \pm 1 \mathrm{~cm}$ width of carapace were maintained in FRP tanks fed twice daily with minced fish meat at $10 \%$ of body weight. Healthy crabs of both sexes were used throughout the experimental period, and each crab was subjected to a single bleed. With the help of fine sterile scissors, right chelate leg was gently lacerated in order to get approximately $3 \mathrm{ml}$ of haemolymph from healthy live animal. To void the risk of haemocyte degranulation and coagulation, haemolymph was readily stabilized with anticoagulant solution (Dextrose- $10.25 \mathrm{~g}$, Tris sodium citrate- $4 \mathrm{~g}$, citric acid $-0.28 \mathrm{~g}, \mathrm{NaCl}-2.10 \mathrm{~g}, \mathrm{D} . \mathrm{H}_{2} \mathrm{O}-500$ $\mathrm{ml}$ ) and stored at $4^{\circ} \mathrm{C}$ until use [25].

Gas chromatography-Mass spectrometry (GC-MS) analysis of $P$. pelagicus heamolymph

As describing by Lawal et al., [26] GC-MS analysis was carried out on a GC-MS (Agilent 7890B GC Connected with 5977A MSD mass spectrometry) comprising an AOC-20i auto-sampler and gas chromatograph interfaced to a mass spectrometer (GC-MS). The instrument is equipped with a VF 5 ms fused silica capillary column of $30 \mathrm{~m}$ length, $0.25 \mathrm{~mm}$ diameter and $0.25 \mu \mathrm{m}$ film thickness. The temperatures employed were; column oven temperature $80^{\circ} \mathrm{C}$, Injection Temp $250^{\circ} \mathrm{C}$ at a pressure of $108.0 \mathrm{kPa}$, with total flow and column flow of $6.20 \mathrm{ml} / \mathrm{min}$ and $1.58 \mathrm{ml} / \mathrm{min}$ respectively. The linear velocity was $46.3 \mathrm{~cm} / \mathrm{sec}$ and a purge flow of $3.0 \mathrm{ml} / \mathrm{min}$. The GC program ion source and interface temperature were $200^{\circ} \mathrm{C}$ and $250^{\circ} \mathrm{C}$ respectively with solvent cut time of $2.50 \mathrm{~min}$. The MS program starting time was $3.00 \mathrm{~min}$ which ended at $30.00 \mathrm{~min}$. with event time of $0.50 \mathrm{sec}$, scan speed of $1666 \mu \mathrm{l} / \mathrm{sec}$, scan range 40-800 ul and an injection volume of 1 $\mu \mathrm{l}$ of the P. pelagicus haemolymph (split ratio 10:1). The total running time of GC-MS was $30 \mathrm{~min}$. The relative percentage of the compounds was expressed as percentage with peak area normalization.

\section{Microbial strains}

Antimicrobial activity of $P$.pelagicus haemolymph was tested against Gram positive Bacillus pumulis (HQ693273), Staphylococcus aureus (ATCC 9542), Enterococcus faecalis (HQ693279.1), Gram negative Morganella Morganii (KC465904), Proteus vulgaris (HQ640434), Pseudomonas aeruginosa (HQ693272), Vibrio parahaemolyticus (KC476545), Citrobacter freundii (KC4665905) bacteria and also pathogenic fungi Candida albicans (MTCC 7315). Testing organisms were grown in nutrient broth and potato dextrose broth (Hi-Media Laboratories, Mumbai, India) at $37^{\circ} \mathrm{C}$ for $24 \mathrm{hrs}$ or $48 \mathrm{hrs}$, subcultured into fresh broth and raised to log phase. By centrifuging at $2000 \mathrm{rpm}$ for $10 \mathrm{~min}$, bacteria and fungus were harvested and washed twice with sterile phosphate buffer saline (PBS) and resuspended in PBS. Taking absorbance of 0.4 at $570 \mathrm{~nm}$, microbial suspensions get standardized to give $10^{9} \mathrm{CFU} / \mathrm{ml}$

\section{Antibacterial and antifungal effect of haemolymph from $P$. pelagicus}

Employing agar well diffusion method, antibacterial and antifungal potent of $P$. pelagicus haemolymph was assessed against Gram positive, Gram negative bacteria include B. pumulis, S. aureus, E. faecalis, M. morganii, $P$. vulgaris, $P$. aeruginosa, $V$. parahaemolyticus, $C$. freundii and also pathogenic fungus $C$. albicans. Overnight cultures of old bacteria and fungi were uniformly spread on the surface of nutrient agar and potato dextrose agar plate using sterile cotton swabs respectively. With the support of sterile cork borer, $7 \mathrm{~mm}$ wells were digged and each well were introduced with various concentration of $P$. pelagicus haemolymph (50,100 and $150 \mu \mathrm{l})$ and incubate for $24 \mathrm{hrs}$ and $48 \mathrm{hrs}$ at $37^{\circ} \mathrm{C}$ for bacteria and fungus respectively. Well devoid of haemolymph was assumed as a control. After incubation, activity was measured in the diameter of millimetre and recorded.

\section{Growth curve analysis}

The impact of haemolymph on the bacterial and fungal growth kinetics was evaluated through growth curve analysis by the method of Maiti et al., [27] with little modifications. In brief, both Gram positive and Gram negative bacteria were cultured in liquid media (nutrient broth and potato dextrose broth) in the presence of haemolymph at three different concentrations $(50,100$ and $150 \mu \mathrm{l})$. Absence of haemolymph in growing media severed as a control. For every 6 hrs interval, absorbance was measured at $600 \mathrm{~nm}$ using UV-visible spectrophotometer (UV-1800; Shimadzu, Japan) and growth curve was plotted.

\section{Effect of $P$. pelagicus heamolymph on protein leakage from bacterial and fungal cell membranes}

Oozing of membrane protein from bacterial and fungal cell wall due to the action of $P$. pelagicus haemolymph was check out through protein leakage assay [28]. Together with diverse concentration of haemolymph $(50,100,150 \mu \mathrm{l})$, microbial cells $\left(10^{9} \mathrm{CFU} / \mathrm{ml}\right)$ were incubated in a shaking incubator at $37^{\circ} \mathrm{C}$ for $6 \mathrm{hrs}$. Subsequently, incubated samples were centrifuged for $30 \mathrm{~min}$ at $300 \mathrm{rpm}$; the resultant supernatant was treated with reagents of Lowry method. At last, O.D was measured at $595 \mathrm{~nm}$ to judge the amount of protein leaked.

\section{Biofilm growth inhibition}

By following the methodology of Sandasi et al. [29] inhibition of biofilm growth was predicted with minor modifications. Prior to the addition of haemolymph, biofilm was allowed to grow in the 96 well plate for $24 \mathrm{hrs}$. After biofilm growth, haemolymph of different concentration was introduced into the wells rather than control well devoid of haemolymph and allowed to incubate for $24 \mathrm{hrs}$ at $37^{\circ} \mathrm{C}$. At the end of incubation, $125 \mu \mathrm{l}$ of ethanol was added to remove the excess of stain from the wells. Finally $100 \mu \mathrm{l}$ of destained solution was transferred to fresh plate from the well to take absorbance at 590 $\mathrm{nm}$ using ELISA plate reader. Percentage of biofilm inhibition was calculated by following formula.

$$
\text { Biofilm inhibition (\%): } \frac{\text { Control absorbance }- \text { Sample absorbance }}{\text { Control absorbance }} \times 100
$$

\section{Biofilm biomass assessment}

Biofilm inhibition of haemolymph was carried out following the 
Citation: Anjugam M, Iswarya A, Indumathi T, Vaseeharan B, Pachaiappan R, et al. (2016) Antibiofilm Competency of Portunus pelagicus Haemolymph and Identification of its Bioactive Compounds. J Aquac Res Development 7: 444. doi: 10.4172/2155-9546.1000444

method of Vinoj et al., [30] with slight modifications. By employing staining technique, biofilm biomass in sterile glass pieces was assessed after the incubation of different concentration of haemolymph along with biofilm formed bacteria. After incubation, glass pieces were removed and gently washed with distilled water in order to remove non adherent bacterial cells. The washed glass pieces were air dried, flooded with the stain of acridine orange $(0.4 \%)$ and crystal violet $(0.1 \%)$ for confocal laser scanning microscopy (Carl Zeiss LSM 710) and inverted light microscopy (Nikon Eclipse Ti 100X) analysis respectively. Prior to visualize the biofilm inhibition under microscope, glass pieces were gently rinsed with distilled water to remove excess stain and the images were photographed at the magnification of $40 \mathrm{X}$.

\section{Results}

Gas Chromatography-Mass Spectrometry analysis (GC-MS) of $P$. pelagicus haemolymph

Chromatogram was referred with the database of spectrum of known components stored in GC-MS library for identifying the compounds related to the peak. From the results of GC-MS analysis, approximately 15 peaks analogous to diverse bioactive compounds with various retention times were identified from the haemolymph of $P$. pelagicus (Table 1). Existence and concentration of bioactive compounds in the haemolymph of $P$. pelagicus was directly proportional to height intensity and retention time of each peak (Figure 1). The first peak

\begin{tabular}{|c|c|c|c|c|c|}
\hline Peak no. & Retention time(RT) & Compound name & Nature of compound & Molecular formula(MF) & Molecular weight (MW) \\
\hline 1. & 22.605 & Phenol 2,4-bis 1,1 -dimethyl ethyl & Phenol & $\mathrm{C}_{14} \mathrm{H}_{22} \mathrm{O}$ & 206 \\
\hline 2. & 27.085 & Hexadecane,2,6 11,5-tetramethyl & Fatty acid & $\mathrm{C}_{20} \mathrm{H}_{42}$ & 282.32 \\
\hline 3. & 29.135 & 3-Hexadecanol & Alcohol & $\mathrm{C}_{16} \mathrm{H}_{34} \mathrm{O}$ & 242.26 \\
\hline 4. & 29.581 & Isopropyl myristate & Ester & $\mathrm{C}_{17} \mathrm{H}_{34} \mathrm{O}_{2}$ & 270.2 \\
\hline 5. & 30.487 & 1,2-Benzenedicarboxylic acid & phthalate & $\mathrm{C}_{16} \mathrm{H}_{22} \mathrm{O}_{4}$ & 278.15 \\
\hline 6. & 31.423 & Bis(2-methyl propyl) ester & phthalate & $\mathrm{C}_{16} \mathrm{H}_{22} \mathrm{O}_{4}$ & 278.15 \\
\hline 7. & 31.832 & Phthalic acid & phthalate & $\mathrm{C}_{17} \mathrm{H}_{24} \mathrm{O}_{4}$ & 292.16 \\
\hline 8. & 32.040 & Hexadecanoic acid & Fatty acid & $\mathrm{C}_{18} \mathrm{H}_{36} \mathrm{O}_{3}$ & 300.26 \\
\hline 9. & 32.366 & Dibutylphthalate & phthalate & $\mathrm{C}_{16} \mathrm{H}_{22} \mathrm{O}_{4}$ & 278.15 \\
\hline 10. & 32.775 & Phthalic acid & phthalate & $\mathrm{C}_{17} \mathrm{H}_{24} \mathrm{O}_{4}$ & 292.16 \\
\hline 11. & 33.191 & Bis(2-pentyl ester) & phthalate & $\mathrm{C}_{18} \mathrm{H}_{26} \mathrm{O}_{4}$ & 306.18 \\
\hline 12. & 33.406 & 1,2 benzenedicarboxylic acid & phthalate & $\mathrm{C}_{20} \mathrm{H}_{30} \mathrm{O}_{4}$ & 334.21 \\
\hline 13. & 33.785 & Di(2-methyl butyl ester) & Ester & $\mathrm{C}_{18} \mathrm{H}_{26} \mathrm{O}_{4}$ & 306.18 \\
\hline 14. & 34.224 & Butyl 3-methyl butyl ester & Ester & $\mathrm{C}_{17} \mathrm{H}_{24} \mathrm{O}_{4}$ & 292.16 \\
\hline 15. & 35.435 & Cyclohexylmethylbutyl ester & Ester & $\mathrm{C}_{19} \mathrm{H}_{26} \mathrm{O}_{4}$ & 318.18 \\
\hline
\end{tabular}

Table 1: Bioactive compounds identified in the heamolymph of $P$. pelagicus through GC-MS analysis.

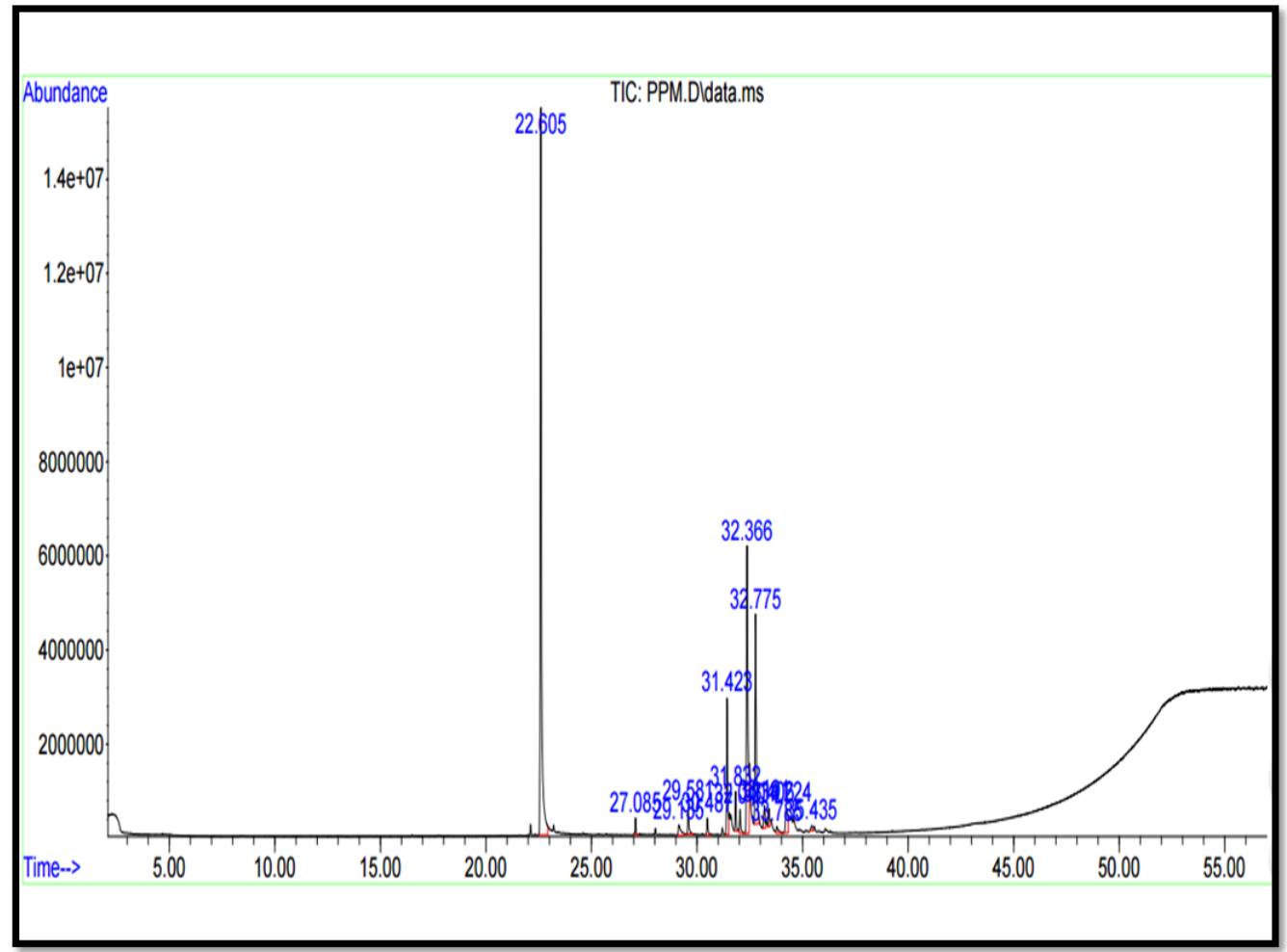

Figure 1: Presence of various bioactive compounds in P. pelagicus haemolymph were confirmed by Gas chromatography - Mass spectrometry spectrum with different retention time. 
Citation: Anjugam M, Iswarya A, Indumathi T, Vaseeharan B, Pachaiappan R, et al. (2016) Antibiofilm Competency of Portunus pelagicus Haemolymph and Identification of its Bioactive Compounds. J Aquac Res Development 7: 444. doi: 10.4172/2155-9546.1000444

Page 4 of 9

\begin{tabular}{|c|c|c|c|c|c|c|}
\hline S.No & Tested organisms & Accession number & Control & $50 \mu \mathrm{l}$ & $100 \mu \mathrm{l}$ & $150 \mu$ \\
\hline 1. & Bacillus pumulis & HQ693273 & - & + & ++ & +++ \\
\hline 2. & Staphylococcus aureus & ATCC 9542 & - & + & ++ & +++ \\
\hline 3. & Enterococcus faecalis & HQ693279.1 & - & + & ++ & +++ \\
\hline 4. & Morganella morganii & KC465904 & - & + & ++ & +++ \\
\hline 5. & Proteus vulgaris & HQ640434 & - & + & ++ & +++ \\
\hline 6. & Pseudomonas aeruginosa & HQ693272 & - & + & ++ & +++ \\
\hline 7. & Vibrio para-haemolyticus & KC476545 & - & + & ++ & +++ \\
\hline 8. & Citrobacter freundii & KC4665905 & - & + & ++ & +++ \\
\hline 9. & Candida albicans & MTCC 7315 & - & + & ++ & +++ \\
\hline \multicolumn{7}{|c|}{$\begin{array}{l}(+) \text { susceptibility inhibition zone lesser than } 5 \mathrm{~mm} \\
(++) \text { susceptibility inhibition zone lesser than } 7 \mathrm{~mm} \\
(+++) \text { susceptibility inhibition zone greater than } 7 \mathrm{~mm} \\
(-) \text { no inhibition }\end{array}$} \\
\hline
\end{tabular}

Table 2: Antibacterial activity of $P$. pelagicus haemolymph against Gram positive (3 Nos), Gram negative ( 5 Nos) bacteria and fungus $C$. albicans.
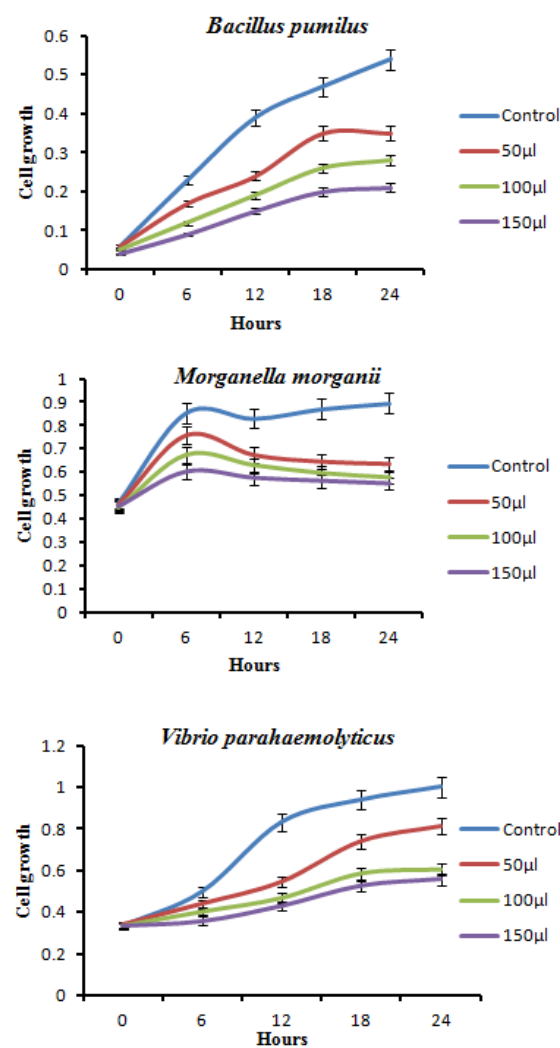
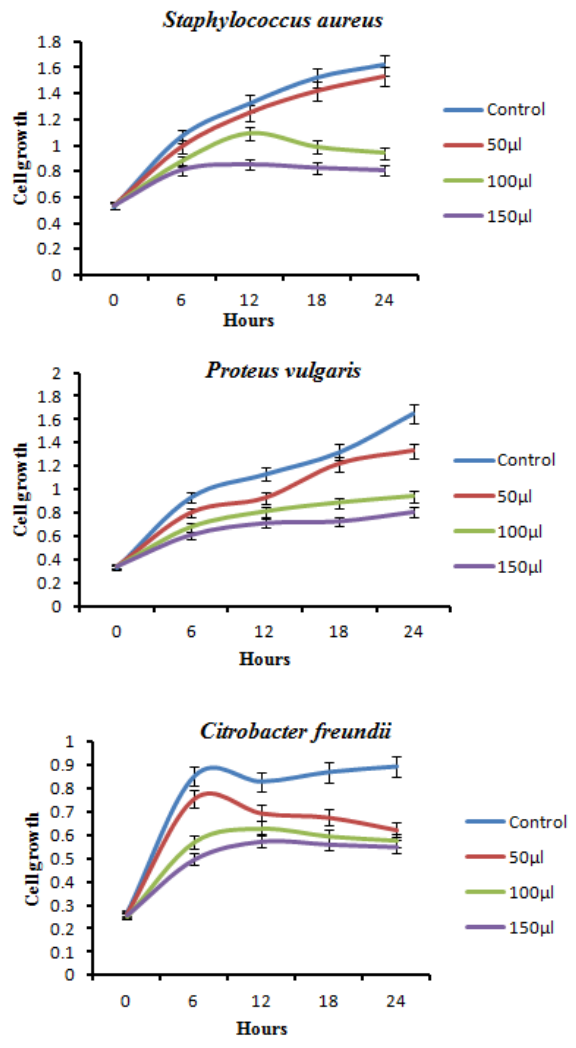
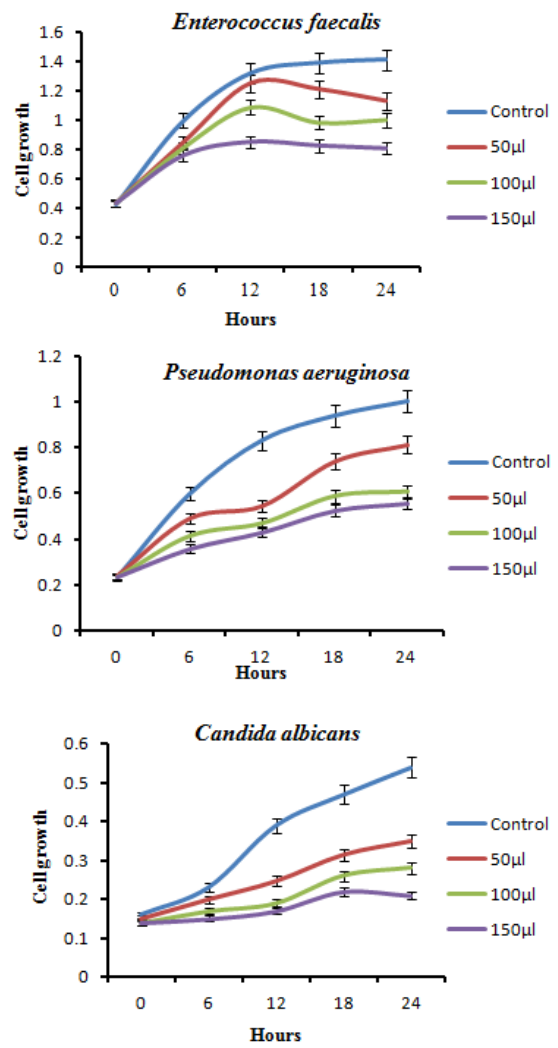

Figure 2: Growth curve analysis of Gram positive (3 No.s), Gram negative (5 No.s) bacteria and fungus C. albicans treated with $P$. pelagicus haemolymph at different concentrations.

corresponding to phenol-2, 4-bis 1, 1- dimethylethyl (206 kDa) with the retention time of 22.605 min displays high concentration whereas cyclohexylmethyl butyl esters $(318.18 \mathrm{kDa})$ with the retention time of 35.435 min shows low concentration abundance in the haemolymph. Biocompounds in $P$. pelagicus haemolymph express different nature of compounds include phenol, fatty acids, alcohol, phthalate and esters. Among that, substance express phthalate nature was more in number. Thus, each compound manifest diverse nature may be actively involved in silencing the life of microbes.

\section{Antibacterial and antifungal activity of haemolymph}

Sensitivity of Gram positive, Gram negative bacteria and fungus C. albicans to crab haemolymph was evaluated by agar well diffusion method. Gram positive and Gram negative bacteria showed high sensitivity when exposed to higher concentration of haemolymph. Haemolymph of $P$. pelagicus was observed to be an effective agent in preventing the growth of Gram positive, Gram negative bacteria and fungus $C$. albicans. After the addition of $P$. pelagicus heamolymph, the intensification of Gram positive ( 3 No.s) and Gram negative ( $5 \mathrm{Nos}$ ) was reduced when compared to the untreated (Table 2). Zone of inhibition was increased at the concentration of 100 and $150 \mu \mathrm{g} / \mathrm{ml}$ and there was no reticence occurs at control. Agar well diffusion assay attested that the concentration of 100 and $150 \mu \mathrm{g} / \mathrm{mL}$ of crab heamolymph showed effective inhibitory activity against tested microbes with different range of zone of inhibition. Increase the concentration of $P$. pelagicus heamolymph showed the increased zone size against both Gram 


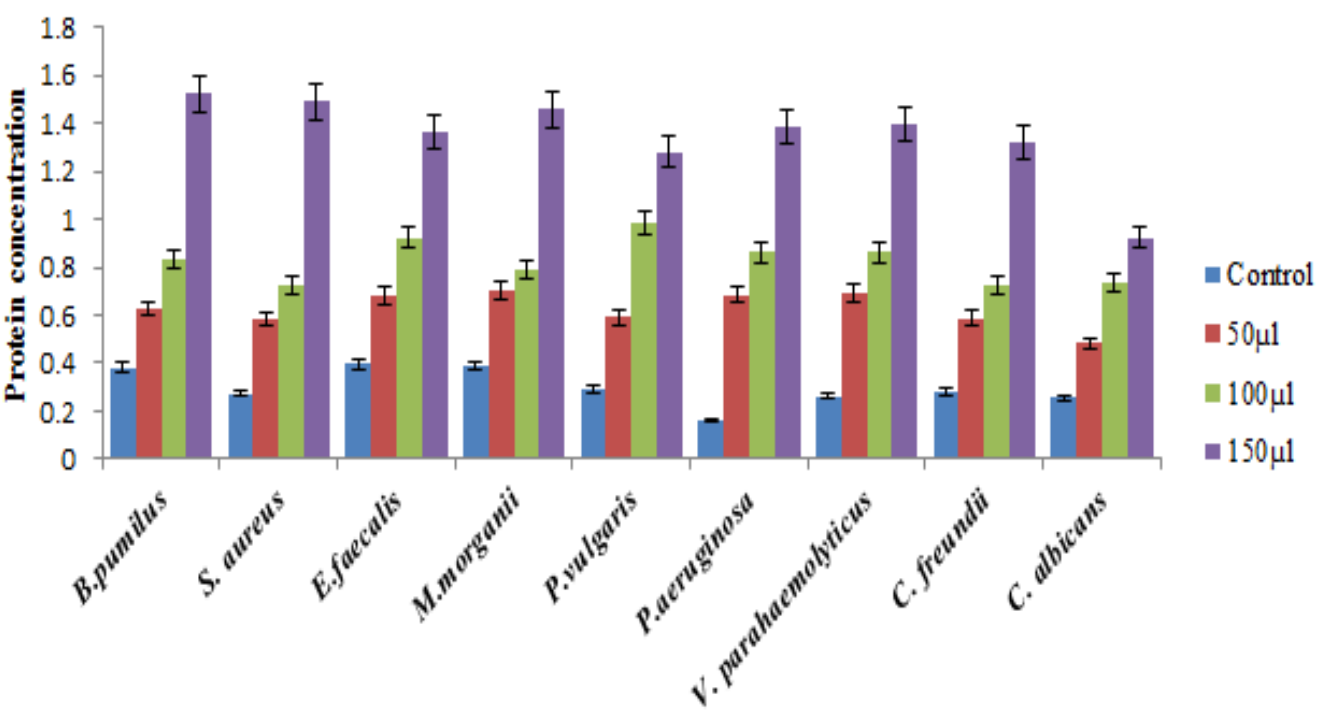

Figure 3: Protein leakage concentration due to bacterial membrane damaging action of $P$. pelagicus haemolymph against Gram positive (3 No.s), Gram negative (5 No.s) bacteria and fungus.

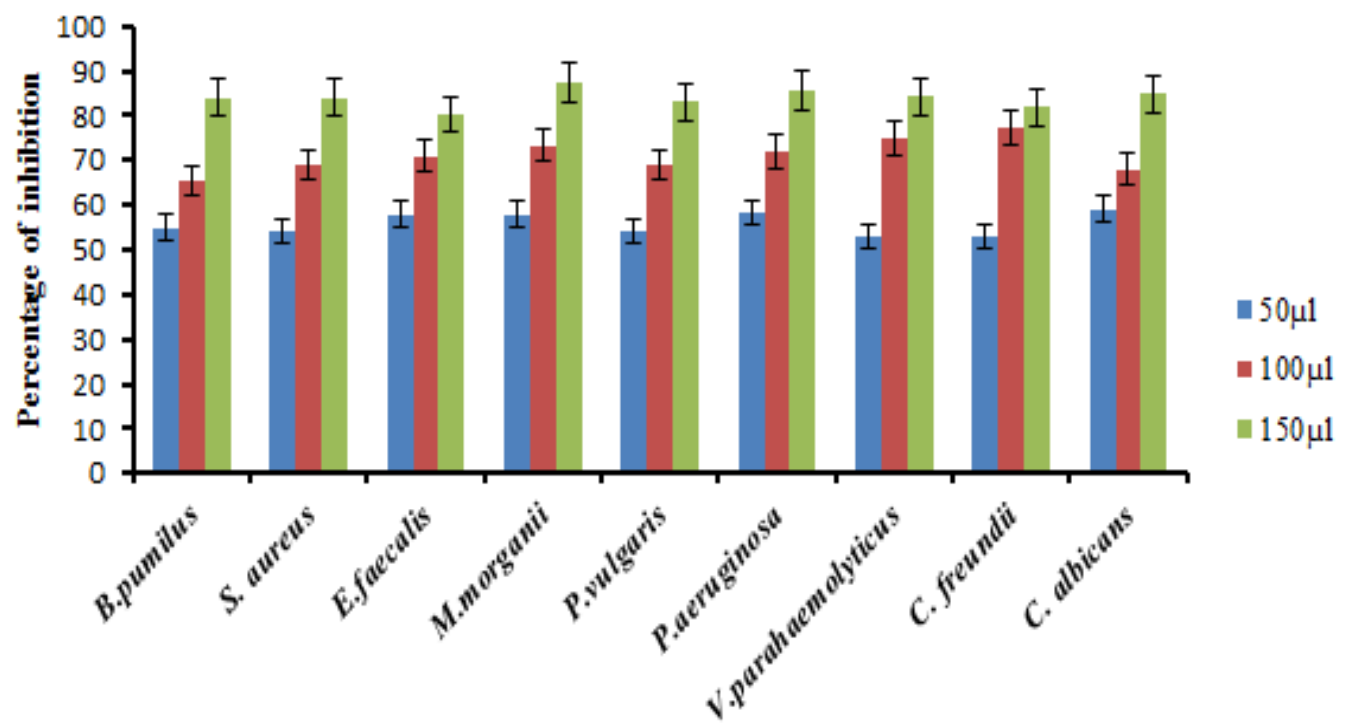

Figure 4: The effect of $P$. pelagicus haemolymph on the growth of microbial biofilm expressed as percentage of inhibition.

positive and Gram negative bacteria. Besides, P. pelagicus heamolymph also exhibits antifungal activity against the fungal pathogen C. albicans.

\section{Growth curve analysis}

The slant of bacterial growth curve was declined in the presence of $P$. pelagicus haemolymph at higher concentration. This explains that, the growth of bacteria was indirectly proportional to haemolymph concentration (Figure 2). The results clearly explain that, at low concentration of haemolymph, the growth of bacteria was delayed and at higher concentration growth was inhibited. Therefore, it can be concluded that haemolymph may acts as bacteriostatic at low concentration and bactericidal at high concentration. It was noticed that, high concentration of haemolymph has the ability to hold the bacterial growth and wipe out it. It was experiential that at lower initial $\mathrm{OD}$, the haemolymph concentration necessary to completely inhibit bacterial growth was also low.

\section{Effect of $P$. pelagicus heamolymph on protein leakage from bacterial and fungal cell membranes}

It was found that haemolymph happen to reason for protein leakage by increasing the membrane permeability of Gram positive, Gram negative bacteria and fungus (Figure 3). At first, protein leakage from the membranes of bacteria and fungus $C$. albicans treated with haemolymph was almost the same as that from cells in the control group. At $6 \mathrm{hrs}$ after incubation, protein leakage from cells treated with haemolymph considerably increased; however, there was no change in the amount of protein leakage from cells in the control group indicating that haemolymph can increase the membrane permeability leads to the release of internal materials. Notably, higher amounts of proteins leaked through the Gram negative membranes compared to those through the Gram positive membranes because of thick peptidoglycan layer. 
Citation: Anjugam M, Iswarya A, Indumathi T, Vaseeharan B, Pachaiappan R, et al. (2016) Antibiofilm Competency of Portunus pelagicus Haemolymph and Identification of its Bioactive Compounds. J Aquac Res Development 7: 444. doi: 10.4172/2155-9546.1000444

Page 6 of 9

\section{Biofilm growth inhibition}

Growth of biofilm inhibition with spectrophotometric assay clearly read out the potential of haemolymph on biofilm inhibition. The result demonstrates, all the tested concentration of haemolymph directly affects the growth of preformed biofilm of all challenged bacteria. Also biofilm growth inhibition conveys, at very low concentration of haemolymph $(50 \mu \mathrm{l})$ noticeable result was observed and thereby effect of haemolymph was more pronounced on biofilm when the concentration get elevated (Figure 4). Take as a whole, haemolymph of a $P$. pelagicus showed more than $75 \%$ potent in inhibit the growth of bacteria.

\section{Antibiofilm potential of $P$. pelagicus haemolymph}

Confocal laser scanning microscopy and light microscopy captures reveals $P$. pelagicus haemolymph effectively disrupt the biofilm construction by reducing the thickness of the exopolysaccharide found on the outer surface of both Gram positive and Gram negative bacteria and also fungal pathogen C. albicans (Figures 5 and 6). The impact on biofilm inhibition was demonstrated with various concentrations of haemolymph have potential inhibitory effect on biofilm formation. At the concentration of $150 \mu \mathrm{l}$ haemolymph acts well upon the bacterial and fungal biofilms and there was a proportional decrease in thickness of biofilm with increased concentration.

\section{Discussion}

Haemolymph of invertebrates pay great attention to perceive novel bioactive compounds for pharmacological utilization. Among invertebrates, crustaceans include crabs acts as a store house of antimicrobial substance with wide range of biomedical properties. On this basis, this current study was undertaken to let out the antimicrobial property of blue swimmer crab $P$. pelagicus haemolymph against various bacterial strains of both Gram positive and Gram negative bacteria comprise B. pumulis, S. aureus, E. faecalis, M. morganii, $P$. vulgaris, $P$. aeruginosa, $V$. parahaemolyticus, $C$. freundii and fungal strain C. albicans. Antimicrobial activity of crab haemolymph has been reported in the haemolymph of the blue crab Callinectes sapidus [31], mud crab Scylla serrata [32,33], Ghost crab

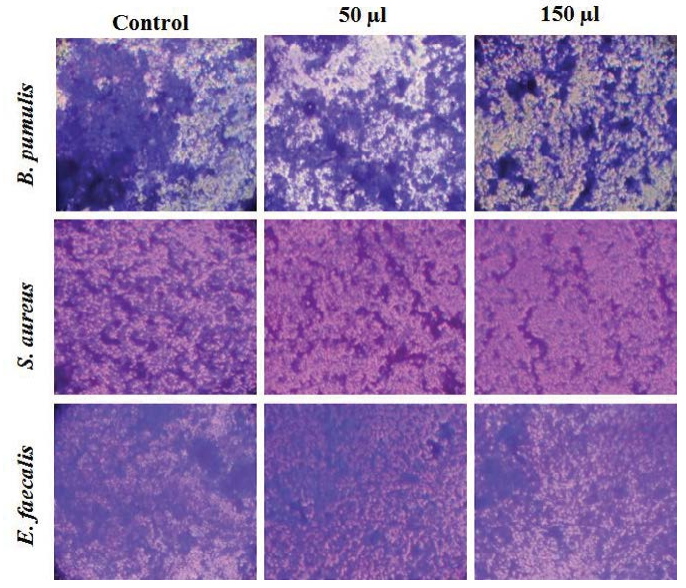

$(5 A)$

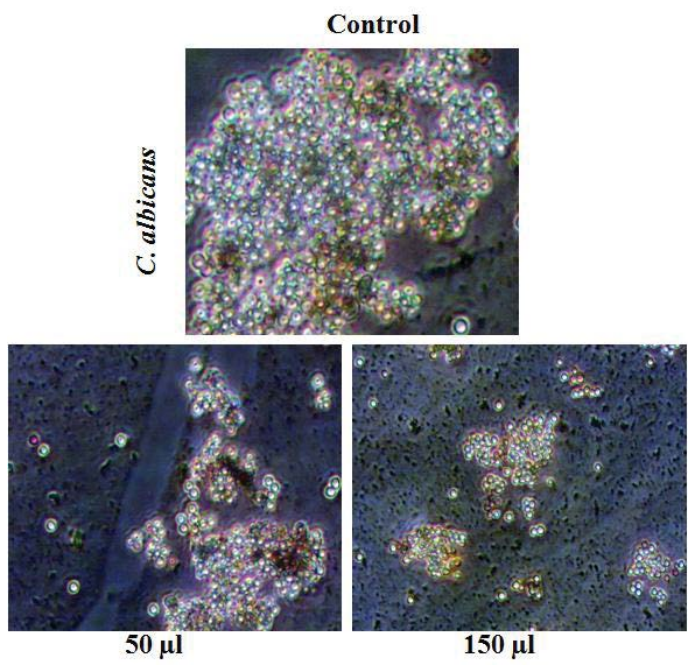

$(5 \mathrm{C})$
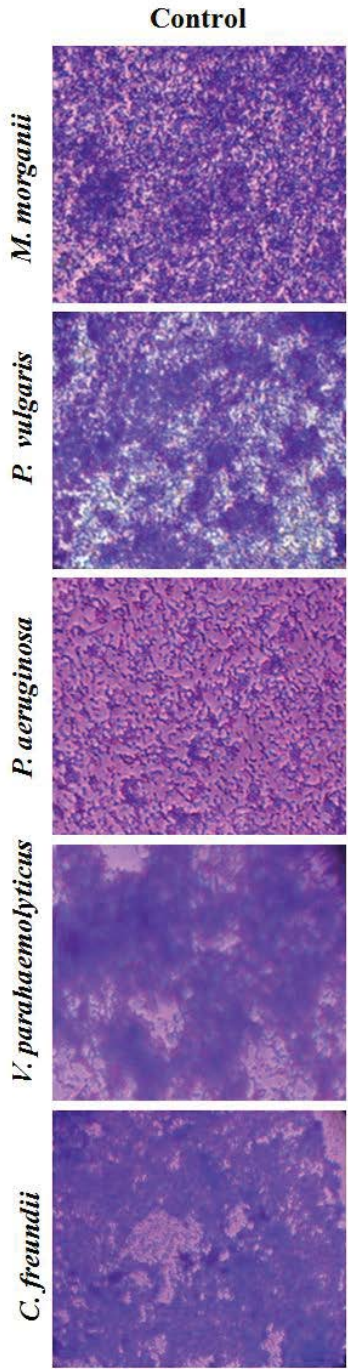

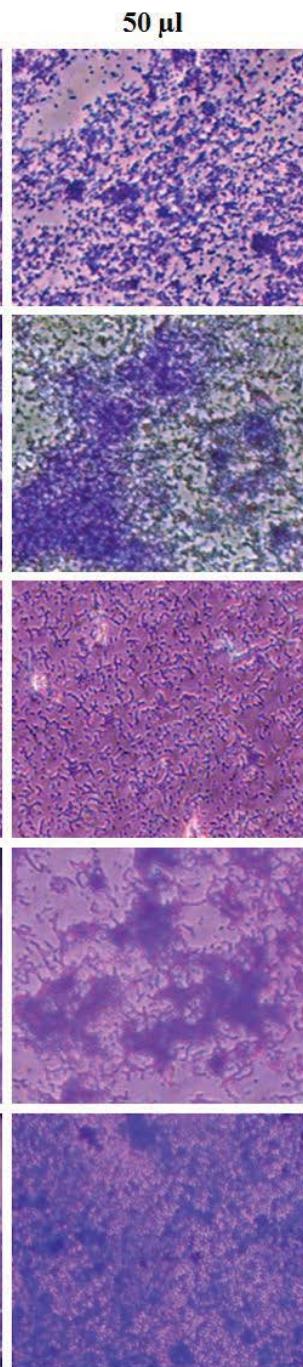

(5B)

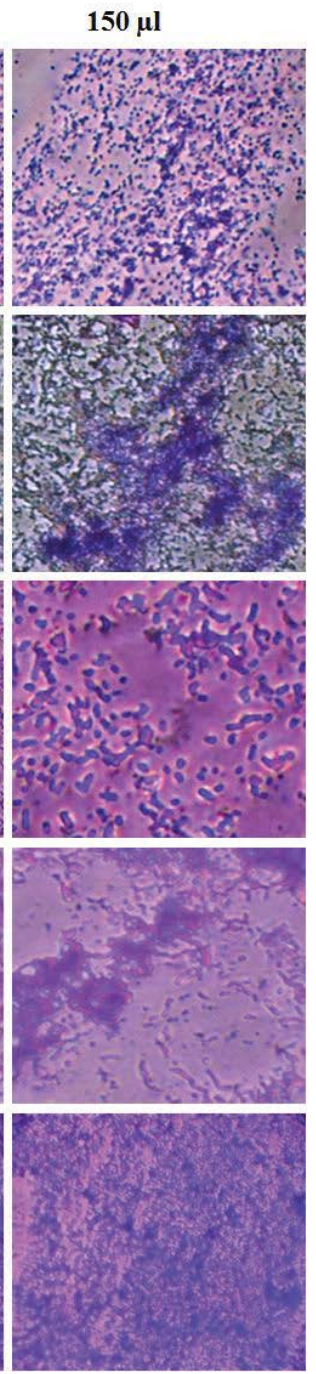

Figure 5: (A and B) Disruption of biofilm formation of Gram positive and Gram negative bacteria by $P$. pelagicus haemolymph was visualized under light microscopy with the satin of crystal violet; (C) Antibiofilm property of haemolymph on fungus C. albicans. 


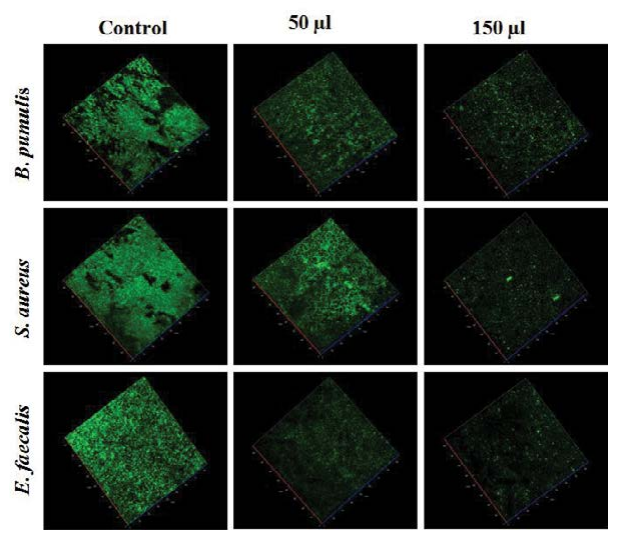

$(6 \mathrm{~A})$

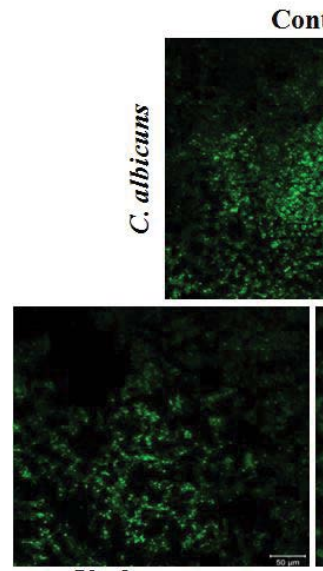

$50 \mu \mathrm{l}$
Control

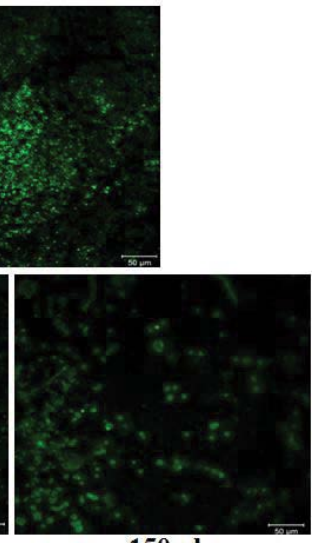

(6C)
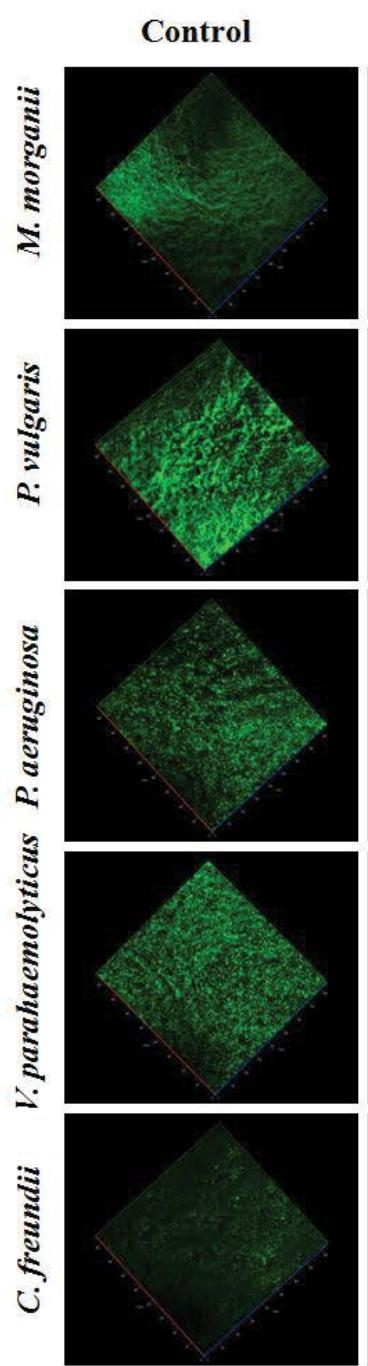

$50 \mu \mathrm{l}$
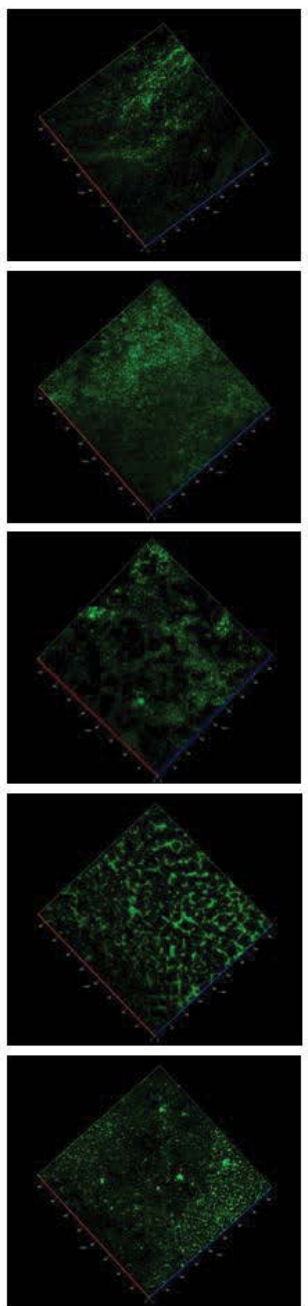

(6B)
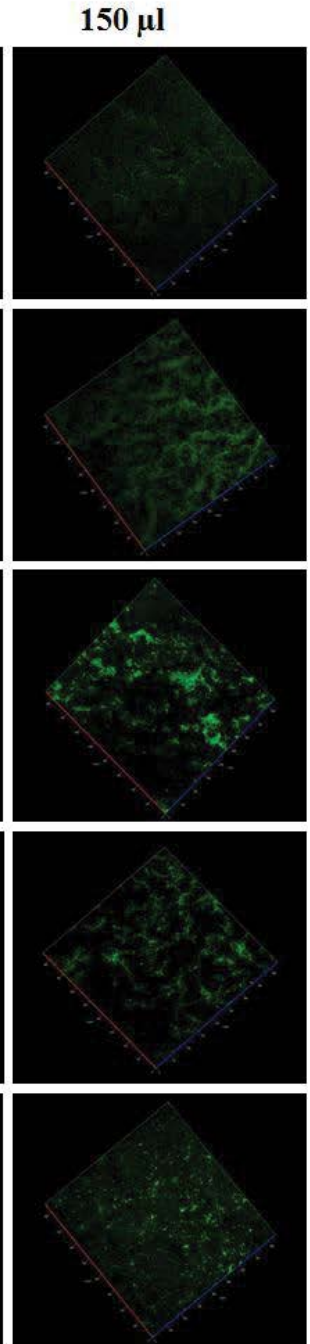

Gram negative bacteria and fungus $C$. albicuns -

Figure 6: $(A, 1$
CLSM view.

Ocypode macrocera [34] and Littoral crab Carcinus maenas [35], As yet, antimicrobial activity of haemolymph get studied, the bioactive compounds behind antimicrobial action is not elucidated. In this study, we report the antimicrobial potent of $P$. pelagicus haemolymph and existence of bioactive compounds answerable for antimicrobial activity. Through GC-MS analysis, haemolymph show 15 important bioactive compounds with varying nature at different retention times notable to have antimicrobial property. Among that, phenol-2, 4-bis (1, 1 dimethylethyl) concentration was abundantly accounted and known to force antibiofilm activity. Studies investigated phenol-2, 4-bis (1, 1 dimethylethyl) from marine origin directly inhibit biofilm forming bacteria Serratia marcescens [36]. In this attempt, phthalate nature compounds occupancy was more number in haemolymph of $P$. pelagicus; thereby its contribution in antibacterial action was higher than other compounds [37,38]. In addition to the above mentioned bioactive compounds, esters, fatty acids, alcohol were actively involved in microbicidal job together with or without other bioactive groups. Thus, haemolymph of $P$. pelagicus certified as rich source of defence molecule against pathogens. In this study, haemolymph of $P$. pelagicus reveals its potent lethal action against 8 selective Gram positive and Gram negative pathogenic bacteria also includes infective fungus $C$. albicans by killing effect measured by zone of inhibition. The mortal action of haemolymph may achieve due to interrupting with bacterial membrane to turn over intracellular mechanisms. Parallel results were accounted in the haemolymph of some brachyuran crab against clinical pathogen $[18,39,40]$. Interfering and inhibition of bacterial growth was important feature for good bioactive substance. In this way, growth kinetics was taking up with bacterial and fungus cultures treated with haemolymph of $P$. pelagicus result in the inhibition of microbial growth. This is attained by interference of $P$. pelagicus haemolymph on log phase and thereby reduces the growth pattern leads death of bacteria. By look over the result of GC-MS chromatogram, fatty acid in the $P$. pelagicus haemolymph go in for the bacterial growth suppression action via creating unfavourable condition to the challenging bacteria [41]. Biofilm- a mass of bacterial colony sheltered by polysaccharide matrix is another serious concern under bacterial infection. Thus far, antimicrobial activity of haemolymph have been reported, antibiofilm activity of haemolymph is still not announced. Output of our study 
reports antibiofilm activity of $P$. pelagicus heamolymph on biofilm construction. In our previous studies, biofilm architecture of different pathogenic bacteria was inhibited by microbial based silver nanoparticles [42], protein based gold nanoparticles [30], pattern recognition protein ß-GBP [21] and essential oil coated gold nanoparticles [43]. This is the first attempt to find out the antibiofilm potential of crab heamolymph. In biofilm, the shelter exopolysaccharide provide great protection to bacterial colonies by preventing the penetration of any antibiotic drugs [44]. However, P. pelagicus heamolymph show exception to the above fact, because it penetrates and disturb the polysaccharide matrix composed by microbial population. This is supported by antibiofilm activity where heamolymph perturb the pool of biofilm forming bacteria, result in collapsing biofilm architecture. CLSM and light microscopic view clearly shows $P$. pelagicus heamolymph upset bacterial cells so that bacterial cells get dispersed from their colony or substratum. The disturbance of $P$. pelagicus haemolymph was accomplished from least concentration $(50 \mu \mathrm{l})$ and increased with high concentration $(150 \mu \mathrm{l})$. In above said action, fatty acid and phenol in $P$. pelagicus haemolymph are highly engaged in producing repulsive action between microbial cells and substratum. Microbial cells from their substratum and so microbial cells get dispersed and biofilm formation was stopped. Also alcoholic compounds in the haemolymph of $P$. pelagicus show ability to disturb bacterial cell membrane. This may cause acidic nature to cytoplasmic environment leads to denaturation of enzymes and other functions get collapsed to kill microbes. Our suggestion correlate with the view of Ingram, 1990 [45] clearly report the killing mechanism of alcohol. By employing Lowry method, protein spill from the bacterial cell membrane was quantified indicating bacterial cell damage due to the action of $P$. pelagicus haemolymph. This clearly demonstrate haemolymph of $P$. pelagicus penetrate into the bacterial cells by increasing bacterial cell membrane flexibility. As a consequence, the present report uncovers the antimicrobial property of $P$. pelagicus haemolymph. Thus, $P$. pelagicus haemolymph acts as a good antimicrobial agent satisfy the needs of pharmaceutical industries in generating novel drugs against antibiotic resistant bacteria. Further studies will be focused towards the elucidation of potential bioactive compounds and their inhibition mechanism on microbial growth.

\section{Conclusion}

In conclusion, haemolymph of $P$. pelagicus displays its potent as antimicrobial agent against some pathogenic bacteria and fungus. As a circulating fluid of crustaceans, haemolymph not only protect the animal, but also bioactive substance rich haemolymph acts as a good antimicrobial agent to mankind. This may attract the attention of pharmaceutical industry to introducing novel drugs with natural activities against multi drug resistant pathogenic microbes.

\section{Acknowledgement}

This work was supported by the Department of Biotechnology (DBT), New Delhi, India, under the Project grants code BT/PR7903/AAquote/3/638/2013.

\section{References}

1. Datta D, Nath TS, Swarnakar S (2015) Bioactive compounds from marine invertebrates for potential medicines - An overview. International Letters of Natural Sciences 34: 42-61.

2. Lordan S, Ross RP, Stanton C (2011) Marine bioactives as functional food ingredients: Potential to reduce the incidence of chronic diseases. Marine Drugs 9: 1056-1100.

3. Aneiros A, Garateix A (2004) Bioactive peptides from marine sources: pharmacological properties and isolation procedures. Journal of Chromatography B 803: 41-53.

4. Hussain S, Fareed S, Ansari S, Khan MS (2012) Marine natural products: A lead for anti-cancer. Journal of Geo- Marine Sciences 41: 27-39.
5. Cragg GM, Grothaus PG, Newman DJ (2009) Impact of natural products on developing new anticancer agents. Chemical Reviews 109: 3012-3043.

6. Jaisson FB, Molmeret M, Fahs A, Dombrowsky LG, Culioli G, et al. (2016) Characterization and anti-biofilm activity of extracellular polymeric substances produced by the marine biofilm-forming bacterium Pseudoalteromonas ulvae strain TC14. Biofouling; The Journal of Bio-adhesion and Biofilm Research 32 547-560.

7. Bhatnagar I, Kim S (2010) Immense essence of excellence: Marine microbial bioactive compounds. Marine Drugs 8: 2673-2701.

8. Mayer F, Mueller S, Malenke E, Kuczyk M, Hartmann JT, et al. (2005) Induction of apoptosis by flavopiridol unrelated to cell cycle arrest in germ cell tumour derived cell lines. Investigational New Drugs 23: 205-211.

9. Wijesekara I, Kim S (2010) Angiotensin-I-converting enzyme (ACE) inhibitors from marine resources: Prospects in the pharmaceutical industry. Marine Drugs 8: 1080-1093.

10. Martins A, Vieira H, Gaspar H, Santons S (2014) Marketed marine natura products in the pharmaceutical and cosmeceutical industries: Tips for success. Marine Drugs 12: 1066-1101.

11. Rawat DS, Joshi MC, Joshi $P$, Atheaya $H(2006)$ Marine peptides and related compounds in clinical trial. Anticancer Agents in Medicinal Chemistry 6: 33-40.

12. Mayer AM, Glaser KB, Cuevas C, Jacobs RS, Kem W, et al. (2010) The odyssey of marine pharmaceuticals: A current pipeline perspective. Trends in Pharmacological Science 31: 255-265.

13. Blunt JW, Copp BR, Munro MHG, Northcote PT, Prinsep MR (2004) Marine natural products. Natural Products Reports RSC 21:1-49.

14. Sivakamavalli J, Rajakumaran P, Vaseeharan B (2012) Prophenoloxidase and immune indices of Indian white shrimp Fenneropenaeus indicus. Journal of Aquaculture Research \& Development 3: 6.

15. Marinho PR, Muricy GRS, Silva MFL, deMarval MG, Laport MS (2008) Antibiotic-resistant bacteria inhibited by extracts and fractions from Brazilian marine sponges. Brazilian Journal of Pharmacognosy 20: 267-275.

16. Vignesh S, Raja A, James RA (2011) Marine drugs: Implication and future studies. International Journal Pharmacology 7: 22-30.

17. Sivakamavalli J, Vaseeharan B (2014) Purification, characterization and functional role of lectin from green tiger shrimp Penaeus semisulcatus. International Journal of Biological Macromolecules 67: 64-70.

18. Veeruraj A, Ravichandran S, Rameshkumar G (2008) Antibacterial activity of crab hemolymph on clinical pathogens. Trends in Applied Sciences and Research 3: 174-181.

19. Sivakamavalli J, Nirosha R, Vaseeharan B (2015) Purification and characterization of a cysteine-rich 14-kDa antibacterial peptide from the granular hemocytes of mangrove crab Episesarma tetragonum and its anti-biofilm activity. Applied Biochemistry and Biotechnology Journal 176: 1084-1101.

20. Shanthi S, Vaseeharan B (2012) cDNA cloning, characterisation and expression analysis of a novel antimicrobial peptide gene penaeidin-3 (Fi-Pen3) from the haemocytes of Indian white shrimp Fenneropenaeus indicus. Microbiological Research 16: 127-134.

21. Anjugam M, Iswarya $A$, Vaseeharan $B$ (2016) Multifunctional role of $\beta-1,3$ glucan- binding protein purified from the haemocytes of blue swimmer crab Portunus pelagicus and in vitro antibacterial activity of reaction product. Fish and Shellfish Immunology 48: 196-205.

22. Stewart JE, Zwicker BM (1972) Natural and induced bactericidal activities in the hemolymph of the lobster; Homarus americanus: products of haemocyteplasma interactions. Canadian Journal of Microbiology 18: 1499-1509.

23. Arul PA, Balasubramanian S, Gunasekaran G, Prakash M, Senthil RP (2011) Control of clinical pathogens by the haemolymph of Paratelphusa hydrodromous, a freshwater crab. ISRN Pharmacology 2011: 1-4

24. Hajirasouli M, Pazook J (2014) Antimicrobial potential of hemolymph and hepatopancreas of Portunus segnis crabs. International Journal of Pharmacy and Pharmaceutical Sciences 6: 601-603.

25. Vaseeharan B, Lin YC, Ko CF, Chiou TT, Chen JC (2007) Molecular cloning and characterisation of a thioester-containing $\alpha 2-$ macroglobulin $(\alpha 2-\mathrm{M})$ from the haemocytes of mud crab Scylla serrata. Fish and Shellfish Immunology 22: $115-130$ 
Citation: Anjugam M, Iswarya A, Indumathi T, Vaseeharan B, Pachaiappan R, et al. (2016) Antibiofilm Competency of Portunus pelagicus Haemolymph and Identification of its Bioactive Compounds. J Aquac Res Development 7: 444. doi: 10.4172/2155-9546.1000444

26. Lawal B, Shittu OK, Adeleke TAR, Ossai PC, Ibrahim AM (2015) GC-MS determination of bioactive constituents of giant African snail (Archachatina maginata) haemolymph. Journal of Pharmacy and Biological Sciences 10: 59-64.

27. Maiti S, Krishnan D, Barman G, Ghosh SK, Laha JK (2014) Antimicrobial activities of silver nanoparticles synthesized from Lycopersicon esculantum extract. Journal of Analytical Science and Technology 5: 40.

28. Kim SH, Lee HS, Ryu DS, Choi SJ, Lee DS (2011) Antibacterial activity of silver-nanoparticles against Staphylococcus aureus and Escherichia coli. Korean J Microbiol Biotechnol 39: 77-85.

29. Sandasi M, Leonard CM, Viljoen P (2010) The in vitro anti-biofilm activity of selected culinary herbs and medicinal plants against Listeria monocytogens. Letters in Applied Microbiology 50: 30-35.

30. Vinoj G, Pati R, Sonawane A, Vaseeharan B (2015) In vitro cytotoxic effects of gold nanoparticles coated with functional AHL Lactonase protein from Bacillus licheniformis and its anti-biofilm activity against Proteus species. Antimicrobial agents and chemotherapy 59: 763-771.

31. Edward NJ, Arroll TA, Fan Z (1996) Specificity some physiochemical characteristics of antibacterial activity from blue crabs Callinectes sapidus. Fish and Shellfish Immunology 6: 403-412.

32. Lin YC, Vaseeharan B, Chen JC (2010) Molecular cloning of mud crab Scylla serrata peroxinectin and its expression following Vibrio alginolyticus and peptidoglycan injections. Fish and Shellfish Immunology 28: 205-211.

33. Hoq MI, Seraj MU, Chowdhury S (2003) Isolation and characterization of antibacterial peptides from the mud crab Scylla serrata. Pakistan Joural of Biological Sciences 6: 1345-1353.

34. Ravichandran S, Sivasubramaninan K, Anbuchezhian RM (2010) Antimicrobial activity from the haemolymph of the crab Ocypode macrocera $(\mathrm{H}$. MilneEdwards 1852). World Applied Sciences Journal 11: 578-581.

35. Schnapp D, Kemp GD, Smith VJ (1996) Purification and characterization of a proline-rich antibacterial peptide, with sequence similarity to bactenecin-7, from the haemocytes of the shore crab, Carcinus maenas. European Journal of Biochemistry 240: 532-539.
36. Padmavathi AR, Abinaya B, Pandian SK (2014)Phenol, 2,4-bis (1,1-dimethylethyl) of marine bacterial origin inhibits quorum sensing mediated biofilm formation in the uropathogen Serratia marcescens. Biofouling 30: 1111-1122.

37. Roy RN, Laskar S, Sen SK (2006) Dibutyl phthalate, the bioactive compound produced byStreptomyces albidoflavus 321.2. Microbiological Research 161: 121-126.

38. Habib MR, Karim MR (2009) Antimicrobial and cytotoxic activity of di-(2ethylhexyl) phthalate and anhydrosophoradiol-3-acetate isolated from Calotropis gigantea (Linn.) Flower. Mycobiology 37: 31-36.

39. Ravichandran S, Kannupandi T (2004) Biochemical changes in decomposing leaves and crabs of Pichavaram mangroves. Biochem Cell Arch 24: 79-88.

40. Ravichandran S, Anthonisami A, Kannupandi T, Balasubramanian T (2007) Leaf choice of herbivorous mangrove crabs. Journal of Fisheries and Aquatic Sciences 1: 26-30

41. Andrew PD, Smith VJ (2010) Antibacterial free fatty acids: activities, mechanisms of action and biotechnological potential. Applied Microbiology and Biotechnology 85: 1629-1642.

42. Shanthi S, David JB, Velusamy P, Vijayakumar S, Cheng TC, et al. (2016) Biosynthesis of silver nanoparticles using a probiotic Bacillus licheniformis Dahb1 and their anti-biofilm activity and toxicity effects in Ceriodaphnia corunta. Microbial Pathogenesis 93: 70-77.

43. Manju S, Malaikozhundan B, Vijayakumar S, Shanthi S, Jaishabanu A, et al. (2016) Antibacterial, antibiofilm and cytotoxic effects of Nigella sativa essential oil coated gold nanoparticles. Microbial Pathogenesis 91: 129-135.

44. Padmavathi A, Periyasamy M, Pandian SK (2015) Assessment of 2,4-di-tertbutylphenol induced modifications in extracellular polymeric substances of Serratia marcescens. Bioresource Technology 188: 185-189.

45. Ingram LO (1990) Ethanol tolerance in alcohol. Critical Reviews in Biotechnology 9: $305-319$. 